\title{
Optimalisasi Performa Mahasiswa Melalui Penggunaan Bahan Ajar Komputasi Matematika Berbantuan Software Mathematica
}

\author{
Abdul Baist', Barra Purnama Pradja ${ }^{2}$, Dian Nopitasari³, \\ Aan Subhan Pamungkas ${ }^{4}$ \\ 1,2,3Universitas Muhammadiyah Tangerang \\ ${ }^{4}$ Universitas Sultan Ageng Tirtayasa
}

Corresponding Author: abdulbaist@umt.ac.id'; barra.pradja@umt.ac.id² ; diannopitasari@umt.ac.id ${ }^{3}$; asubhanp@untirta.ac.id ${ }^{4}$

DOI: http://dx.doi.org/10.15294/kreano.v10i2.21244

Received : September 26 2019; Accepted: December 12019; Published: December 42019

\begin{abstract}
Abstrak
Performa mahasiswa memiliki peran penting dalam menghasilkan lulusan yang berkualitas. Kurang optimalnya performa mahasiswa terlihat dari hasil belajar mahasiswa pada mata kuliah Persamaan Diferensial rata-rata sekitar 70 dan masih ada yang mendapatkan nilai kurang dari 70 sekitar 38\%, serta kurangnya kemandirian belajar mahasiswa. Oleh karenanya optimalisasi performa mahasiswa perlu dilakukan. Tujuan dari penelitian ini adalah untuk mendapatkan optimalisasi performa mahasiswa melalui penggunaan bahan ajar komputasi matematika berbantuan software Mathematica. Kemandirian belajar dan hasil belajar mahasiswa dijadikan sebagai sasaran performa mahasiswa yang akan dioptimalkan. Penelitian ini dilaksanakan di Program Studi Pendidikan Matematika FKIP Universitas Muhammadiyah Tangerang yang berjumlah 24 mahasiswa pada mata kuliah Persamaan Diferensial menggunakan bahan ajar Komputasi Matematika Berbantuan Software Mathematica. Penelitian ini merupakan penelitian kuasi eksperimen dengan desain eksperimen yang digunakan adalah one-group pretest-posttest design. Hasil yang didapat dari penelitian ini adalah terdapat perbedaan yang signifikan antara sebelum dan sesudah penggunaan bahan ajar untuk kemandirian belajar dan hasil belajar mahasiswa melalui uji t. Rata-rata peningkatan persentase kemandirian belajar dan hasil belajar mahasiswa secara berturut-turut sebesar $7 \%$ dan $24 \%$.
\end{abstract}

\begin{abstract}
Students' performance has an important role in producing quality graduates. Less optimal students' performance can be seen from student learning outcomes in Differential Equation courses an average of around 70 and there are still those who score less than 70 about 38\%, and lack of students' self regulated learning. Therefore, optimizing students' performance needs to be done. The purpose of this study is to obtain the optimization of students' performance using computational mathematics teaching materials assisted by Mathematica software. Self regulated learning and student learning outcomes are targeted as students' performance to be optimized. This research was conducted in the Mathematics Education Study Program FKIP Muhammadiyah University of Tangerang, totaling 24 students in the Differential Equation course using Mathematica Software Computational Mathematics teaching material. This research is a quasiexperimental research with the experimental design used is a one-group pretest-posttest design. The results obtained from this study are that there are significant differences between before and after the use of teaching materials for self-regulated learning and student learning outcomes through t-test. The average increase in the percentage of selfregulated learning and student learning outcomes are $7 \%$ and $24 \%$, respectively.
\end{abstract}

Keywords: optimization; students' performance; teaching materials 


\section{PENDAHULUAN}

Era globalisasi merupakan sebuah era di mana orang-orang di suatu negara dapat terhubung dengan orang-orang di negara lain disebabkan oleh kemajuan teknologi komunikasi dan transportasi. Perpindahan penduduk dari suatu negara ke negara lain menjadi hal yang lumrah. Globalisasi merambah kepada globalisasi ekonomi sehingga berkembang sebuah kebijakan perdagangan bebas (Firmansyah \& Hendra, 2015). Salah satu akibat dari perdagangan bebas adalah munculnya kebijakan yang salah satunya memberi kesempatan orang dari suatu negara dapat bekerja di negara lain (Putra, 2018). Keadaan ini tentu saja memunculkan persaingan yang semakin ketat dalam lapangan pekerjaan bagi negara yang didatangi oleh pekerja asing.

Indonesia sebagai salah satu negara yang mengalami era globalisasi tidak dapat menghindari dampak ini. Pemerintah telah membuat kebijakan tentang pekerja asing melalui Peraturan Presiden Nomor 20 Tahun 2018. Meski begitu dampak negatif dari keadaan ini tak dapat dihindari. Suyanto (2018) menganggap bahwa hal ini berisiko menyebabkan terjadinya proses marginalisasi pencari kerja domestik karena mempersempit peluang tenaga kerja lokal.

Bagi mahasiswa, yang nantinya akan bekerja setelah mereka lulus, tentunya perlu mempersiapkan diri dengan keadaan ini. Perguruan Tinggi sebagai salah satu tempat untuk menghasilkan lulusan juga perlu menyiapkan diri agar dapat menghasilkan lulusan yang berkualitas. Lulusan yang mampu bersaing di era globalisasi saat ini dan masa yang akan datang. Kualitas lulusan mahasiswa dari suatu perguruan tinggi dapat dilihat dari performa akademiknya. Performa akademik memiliki peran penting dalam menghasilkan lulusan yang berkualitas (Mushtaq \& Khan, 2012). Tiap institusi pendidikan memiliki kebijakan masing-masing dalam mengukur performa akademik mahasiswa (Cerna \& Pavliushchenko, 2015).

Performa akademik merupakan luaran dari tujuan pendidikan yang dicapai oleh siswa atau guru. Performa akademik juga berarti bagaimana siswa menghadapi studi mereka dan bagaimana mereka menyelesaikan tugas yang diberikan oleh guru (Nalah, 2014). Sementara itu (Jayanthi, Balakrishnan, Lim Siok Ching, Aaqilah Abdul Latiff, \& Nasirudeen, 2014) mengatakan bahwa performa akademik menurut Cambridge University Reporter biasanya didefinisikan sebagai performa ujian. Malsawmtluanga dan Fanai (2018) mengatakan bahwa performa akademik merupakan tingkat pencapaian tujuan pendidikan yang telah dicapai oleh siswa, guru, atau institusi pendidikan.

Beberapa peneliti menggunakan IP semester untuk menilai performa akademik. Hal ini seperti yang dilakukan oleh Katsikas \& Panagiotidis (2010), dan Arshad et al (2015). Ada juga peneliti yang menggunakan IPK sebagai nilai performa akademik. Hal ini seperti yang dilakukan oleh Remali et al (2013); dan Jayanthi et al, (2014). Sementara Mushtaq \& Khan (2012) menggabungkan keduanya.

Berdasarkan pengamatan yang telah dilakukan oleh penulis pada mata kuliah Persamaan Diferensial, hasil belajar yang didapat oleh mahasiswa kurang optimal. Terlihat dari hasil belajar mahasiswa pada mata kuliah Persamaan Diferensial rata-rata sekitar 70 dan sekitar 38\% mendapatkan nilai kurang dari 70. Sementara itu, kemandirian belajar mahasiswa masih kurang di mana hal ini terlihat pada partisipasi aktif yang masih kurang dari mahasiswa pada kegiatan belajar mengajar di kelas, masih mengandalkan teman yang pintar untuk mengerjakan tugas, dan menunggu jawaban untuk tugas tersebut.

Kemandirian belajar merupakan kegiatan belajar aktif yang muncul dari dalam diri individu dengan atau tanpa bantuan orang lain dalam hal penentuan tujuan belajar, memilih strategi dan melaksanakan rancangan belajarnya, dan mengevaluasi hasil belajarnya (Lowry, 1989; Mudjiman, 2009; Sumarmo, 2004; Tahar \& Enceng, 2006; Tarmidi \& Rambe, 2010). Kemandirian belajar memiliki hubungan dengan capaian akademik. Seperti yang telah dilakukan oleh beberapa peneliti dalam hasil penelitian mereka terlihat bagaimana hubungan antara kemandirian belajar dengan capaian akademik (Arsal, 2009; Mega, Ronconi, \& De Beni, 2014; Valle et al., 2008; 
Zumbrunn, Tadlock, \& Roberts, 2011)

Mata kuliah Persamaan Diferensial merupakan mata kuliah yang membahas tentang suatu bentuk persamaan yang memuat turunan satu atau lebih variabel tak bebas terhadap satu atau lebih variabel bebas suatu fungsi (Asyhar \& Asmarani, 2016). Kendala yang dihadapi oleh mahasiswa pada mata kuliah ini di antaranya adalah kurangnya motivasi dan strategi belajar yang kurang tepat. Mengenai hal ini Rejeki dan Setyaningsih (2016) menyarankan penggunaan Computer Algebraic System (CAS) dalam pembelajaran mata kuliah Persamaan Diferensial. Software Mathematica sebagai salah satu CAS telah digunakan oleh beberapa peneliti dalam pembelajaran yang berkaitan dengan Persamaan Diferensial (Faisal, Karim, \& Kamil, 2011; Hothi \& Bisht, 2013; Jonassen, 2002; Lázaro, 2015; Mokhasi, Adduci, \& Kapadia, 2012)

Bahan ajar yang akan digunakan dalam penelitian ini adalah bahan ajar Komputasi Matematika Berbantuan Software Mathemaica yang dibuat oleh (Baist, Firmansyah, \& Pamungkas, 2019). Bahan ajar tersebut dibuat untuk membantu mahasiswa dalam mempelajari komputasi matematika secara mandiri. Terdapat bab tentang penggunaan software Mathematica pada materi Persamaan Diferensial pada bahan ajar tersebut. Oleh karenanya peneliti tertarik untuk mencoba bahan ajar tersebut untuk digunakan oleh mahasiswa pada mata kuliah Persamaan Diferensial. Diharapkan performa mahasiswa pada mata kuliah tersebut dapat dicapai dengan optimal.

\section{METODE}

Penelitian dilaksanakan di Program Studi Pendidikan Matematika FKIP Universitas Muhammadiyah Tangerang yang berjumlah 24 mahasiswa pada mata kuliah Persamaan Diferensial. Pemilihan sampel menggunakan teknik purposive sampling, pertimbangan dalam penelitian ini adalah sampel tidak bisa diacak sebagaimana mestinya. Pertimbangan berikutnya adalah masing-masing subyek sudah diidentifikasi dari aspek self regulated dan kemampuan awal matematikanya.

Penelitian ini merupakan penelitian kuasi eksperimen dengan desain eksperimen yang digunakan adalah one-group pretest- posttest design. Terdapat satu kelompok yang akan diteliti dan unrandomized. Kelompok ini akan diberikan skala awal kemandirian belajar atau self regulated learning (SRL) dan tes hasil belajar sebelum pembelajaran dengan bahan ajar yang didesain khusus serta skala akhir self regulated learning (SRL) dan tes hasil belajar untuk melihat hasil sesudah diberi pembelajaran tersebut. Desain ini dijelaskan sebagai berikut (Cohen, Manion, \& Morrison, 2018): Pengukuran awal dilakukan terhadap kelompok pada variabel terikat $\left(O_{1}\right)$ dalam penelitian ini skala awal SRL dan tes hasil belajar (pretest), dan kemudian memperkenalkan manipulasi eksperimental $(X)$, dalam penelitian ini pembelajaran dengan bahan ajar yang didesain khusus. Setelah perlakuan eksperimental, peneliti sekali lagi mengukur SRL dan hasil belajar $\left(\mathrm{O}_{2}\right)$ dan melanjutkan untuk memperhitungkan perbedaan antara skor pretest dan posttest dengan mengacu pada efek $X$.

Data kemandirian belajar mahasiswa didapat dari penggunaan angket yang dimodifikasi dariYandari et al (2018). Sementara itu hasil belajar mahasiswa didapat dari instrumen tes hasil belajar pada mata kuliah Persamaan Diferensial.

Optimalisasi performa akademik yang dimaksud dalam penelitian ini adalah peningkatan kemandirian belajar dan hasil belajar mahasiswa. Rumus gain Hake (2002) digunakan untuk mengetahui peningkatan kemandirian belajar dan hasil belajar mahasiswa. Berikut ini rumusnya:

$g=\frac{\% \text { posttest }-\% \text { pretest }}{100 \%-\% \text { pretest }}=\frac{\% \text { posttest }-\% \text { pretest }}{100 \%-\% \text { pretest }}$

\section{HASIL DAN PEMBAHASAN}

\section{Kemandirian Belajar}

Gambar 1 menampilkan hasil rata-rata pretest dan posttest persentase kemandirian belajar mahasiswa. Gambar 1 memperlihatkan perubahan yang terjadi antara sebelum dan sesudah menggunakan bahan ajar yang dibuat oleh Baist, et al (2019). Sebelum penggunaan bahan ajar tersebut rata-rata persentase kemandirian belajar sebesar $64 \%$ sedangkan setelah penggunaan bahan ajar sebesar $68 \%$. Terlihat pula dari Gambar 1 bahwa terdapat peningkatan kemandirian belajar mahasiswa antara sebelum dan sesudah 
penggunaan bahan ajar tersebut.

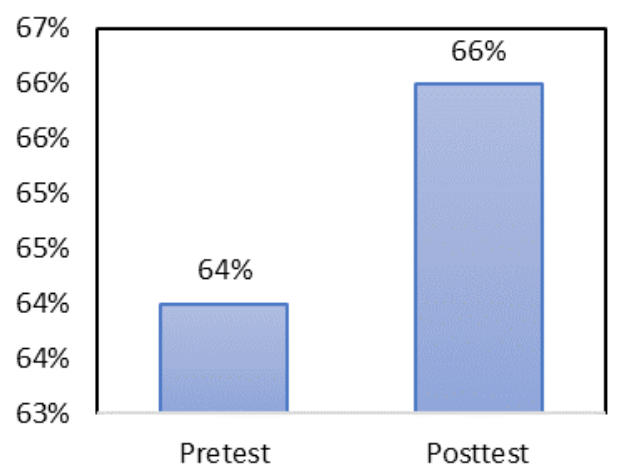

Gambar 1 Persentase Kemandirian Belajar Mahasiswa pada Pretest dan Posttest

Perbedaan yang terjadi perlu ditelaah lebih lanjut, apakah perbedaan tersebut signifikan atau tidak. Pengujian dengan menggunakan uji $t$ digunakan untuk mengetahui hal tersebut.

Tabel 1. Kemandirian Belajar Tests of Normality

\begin{tabular}{ccccccc}
\hline \multirow{3}{*}{ Skor } & \multicolumn{3}{c}{ Kolmogorov- } & \multicolumn{3}{c}{ Shapiro-Wilk } \\
\cline { 2 - 7 } & $\begin{array}{c}\text { Statis- } \\
\text { tic }\end{array}$ & df & Sig. & $\begin{array}{c}\text { Statis- } \\
\text { tic }\end{array}$ & df & Sig. \\
\hline Pretest & .093 & 24 & .941 & 24 & .169 \\
Posttest & .123 & 24 & .967 & 24 & .587 \\
\hline
\end{tabular}

Variabel: Kemandirian Belajar

*. This is a lower bound of the true significance.

a. Lilliefors Significance Correction

Tabel 2. Kemandirian Belajar Paired Samples Test (Pretest-posttest)

\begin{tabular}{|c|c|c|c|c|c|c|}
\hline \multicolumn{4}{|c|}{ Paired Differences } & \multirow{3}{*}{$\mathrm{t}$} & \multirow{3}{*}{ df } & \\
\hline \multirow[t]{2}{*}{ Mean } & \multirow[t]{2}{*}{$\begin{array}{l}\text { Std. } \\
\text { De- } \\
\text { via- } \\
\text { tion }\end{array}$} & \multirow[t]{2}{*}{$\begin{array}{l}\text { Std. } \\
\text { Error } \\
\text { Mean }\end{array}$} & $\begin{array}{c}95 \% \text { Confi- } \\
\text { dence Interval } \\
\text { of the Differ- } \\
\text { ence }\end{array}$ & & & Sig. \\
\hline & & & Lower Upper & & & \\
\hline-5.292 & 8.019 & 1.637 & $-8.678-1.906$ & -3.233 & 23 & .004 \\
\hline
\end{tabular}

Berdasarkan Tabel 1 hasil pengujian normalitas dari data pretest dan posttest untuk kemandirian belajar adalah berdistribusi normal. Hal ini berdasarkan nilai Sig. yang lebih besar dari 0,05. Sementara itu, pengujian dengan uji $t$ didapat bahwa terdapat perbedaan yang signifikan antara pretest dan posttest untuk kemandirian belajar. Hal ini berdasarkan nilai Sig. (2-tailed) yang lebih kecil dari 0,05 pada Tabel 2. Sementara itu melalui penggu- naan rumus gain Hake (2002) didapatkan bahwa rata-rata peningkatan kemandirian belajar sebesar $7 \%$.

Perbedaan yang terjadi antara sebelum dan sesudah pemberian perlakuan melalui pemberian bahan ajar yang telah dibuat pada penelitian sebelumnya menunjukkan bahwa bahan ajar tersebut berpengaruh terhadap kemandirian belajar. Bahan ajar yang didesain oleh Baist et al (2019) merupakan bahan ajar yang didesain untuk mengembangkan kemandirian belajar mahasiswa. Hal ini sejalan dengan pendapat Ana \& Achdiani (2015) yang mengatakan bahwa pemberian strategi yang tepat (dalam hal ini penggunaan bahan ajar yang tepat) oleh dosen dapat membantu meningkatkan kemandirian belajar mahasiswa.

\section{Hasil Belajar}

Gambar 2 menampilkan hasil rata-rata pretest dan posttest persentase hasil belajar mahasiswa.

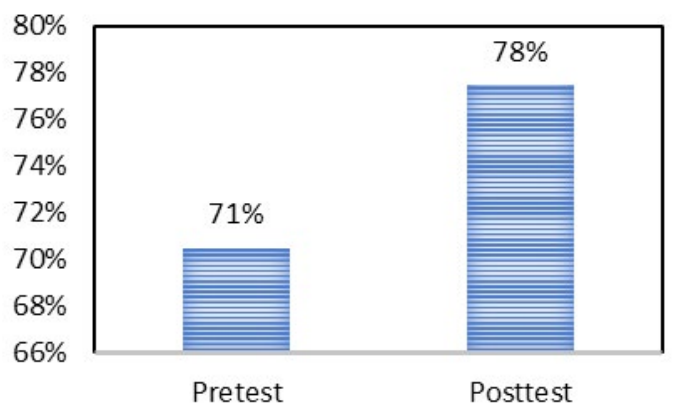

Gambar 2. Persentase Hasil Belajar Mahasiswa pada Pretest dan Posttest

Terlihat dari Gambar 2 terdapat perbedaan antara sebelum dan sesudah menggunakan bahan ajar yang dibuat oleh Baist et al (2019). Sebelum penggunaan bahan ajar tersebut persentase hasil belajar sebesar $71 \%$ sedangkan setelah penggunaan bahan ajar sebesar $78 \%$.

Tabel 3. Hasil Belajar Mahasiswa Tests of Normality (Variabel Hasil Belajar Mahasiswa)

\begin{tabular}{|c|c|c|c|c|c|c|}
\hline \multirow[t]{2}{*}{ Nilai } & \multicolumn{3}{|c|}{$\begin{array}{l}\text { Kolmogorov- } \\
\text { Smirnov }\end{array}$} & \multicolumn{3}{|c|}{ Shapiro-Wilk } \\
\hline & & $\mathrm{df}$ & Sig. & & $\mathrm{df}$ & Sig. \\
\hline & .168 & 24 & .079 & .958 & 24 & .409 \\
\hline & .274 & 24 & .000 & .770 & 24 & .000 \\
\hline
\end{tabular}

a. Lilliefors Significance Correction 
Berdasarkan Tabel 3 hasil pengujian normalitas dari data pretest berdistribusi normal tetapi posttest untuk hasil belajar adalah tidak berdistribusi normal. Hal ini berdasarkan nilai Sig. yang lebih besar dari 0,05 untuk pretest dan nilai Sig. yang lebih kecil dari 0,05 untuk posttest. Oleh karenanya pengujian selanjutnya menggunakan uji non-parametrik yaitu uji Wilcoxon.

Tabel 4. Test Statistics ${ }^{\mathrm{a}}$

\begin{tabular}{cc}
\hline & Posttest - Pretest \\
\hline$Z$ & $-3.692^{\mathrm{b}}$ \\
Asymp. Sig. (2-tailed) & .000 \\
\hline
\end{tabular}

a. Wilcoxon Signed Ranks Test

b. Based on negative ranks.

Pengujian dengan uji Wilcoxon didapat bahwa terdapat perbedaan yang signifikan antara pretest dan posttest untuk hasil belajar. Hal ini berdasarkan nilai Asymp. Sig (2-tailed) yang lebih kecil dari 0,05 pada Tabel 4. Sementara itu melalui penggunaan rumus gain Hake (2002) didapat bahwa rata-rata peningkatan hasil belajar sebesar $24 \%$.

Bahan ajar yang didesain oleh Baist et al (2019) memiliki tampilan yang menarik sesuai dengan prinsip VISUALS yang diungkapkan oleh Mukminan (Nurseto, 2011). Ketika mahasiswa tertarik dalam menggunakan bahan ajar tersebut maka mahasiswa akan merasa nyaman dalam mempelajari materi yang ada pada bahan ajar tersebut termasuk soal-soal latihan yang ada di dalamnya. Melalui soalsoal latihan yang dikerjakan oleh mahasiswa secara mandiri tentunya akan dapat meningkatkan kemampuannya, dengan kata lain dapat meningkatkan hasil belajar mahasiswa. Selaras dengan apa yang diungkapkan Ningsih \& Jayanti (2016) bahwa kemandirian belajar yang meningkat maka hasil belajar dapat meningkat.

\section{PENUTUP}

\section{Simpulan}

Optimalisasi performa mahasiswa dalam penelitian ini, yaitu kemandirian belajar dan hasil belajar, melalui penggunaan bahan ajar komputasi matematika berbantuan software Mathematica pada mata kuliah Persamaan Diferensial berhasil dilakukan. Terdapat

perbedaan kemandirian belajar dan hasil belajar antara sebelum dan sesudah penggunaan bahan ajar tersebut. Melalui pengujian statistik terbukti bahwa perbedaan tersebut signifikan. Peningkatan yang didapat untuk kemandirian belajar sebesar $7 \%$ sedangkan hasil belajar sebesar $24 \%$. Dapat dikatakan bahwa bahan ajar yang digunakan dalam penelitian ini memiliki pengaruh terhadap kemandirian belajar dan hasil belajar mahasiswa.

\section{UCAPAN TERIMA KASIH}

Terima kasih kami sampaikan kepada Kementerian Riset, Teknologi, dan Pendidikan Tinggi yang telah memberikan dana penelitian melalui hibah Penelitian Dosen Pemula (PDP).

\section{DAFTAR PUSTAKA}

Ana, A., \& Achdiani, Y. (2015). Penerapan Self Regulated Learning Berbasis Internet Untuk Meningkatkan Kemandirian Belajar Mahasiswa. Innovation of Vocational Technology Education, 11(1), 15-22.

Arsal, Z. (2009). The impact of self-regulation instruction on mathematics achievements and attitudes of elementary school students. Eğitim Bilimleri Dergisi, 34(152), 1-12.

Arshad, M., Syed, M. I. H. Z., \& Khalid, M. (2015). Self-esteem and academic perfromance among university students. Journal of Education and Practice, 6(1), 156-162.

Asyhar, B., \& Asmarani, D. (2016). Mengatasi Kesulitan Mahasiswa Tentang Materi Persamaan Diferensial Menggunakan Bimbingan Belajar Individual (Face To Face Relationship) Berbantuan Program Maple. Jurnal Pendidikan Matematika, 2(1), 23-30.

Baist, A., Firmansyah, M. A., \& Pamungkas, A. S. (2019). Desain Bahan Ajar Komputasi Matematika Berbantuan Software Mathematica Untuk Mengembangkan Kemandirian Belajar Mahasiswa. FIBONACCI: Jurnal Pendidikan Matematika Dan Matematika, 5(1), 29-36.

Cerna, M. A., \& Pavliushchenko, K. (2015). Influence of Study Habits on Academic Performance of International College Students in Shanghai. Higher Education Studies, 5(4), 42-55.

Cohen, L., Manion, L., \& Morrison, K. (2018). Research Methods in Education (8th ed.). New York: Routledge.

Faisal, M., Karim, A., \& Kamil, A. A. (2011). Mathematica as a tool for studying Mathematics in distance learning environment. Malaysian Journal of Distance Education, 13(2), 95-107.

Firmansyah, H., \& Hendra, E. (2015). Implikasi Globalisasi Ekonomi Dan Perdagangan Bebas Terhadap Stabilitas Nilai Rupiah. Asy-Syari'Ah, 17(1), 45-54. 
Hake, R. R. (2002). Relationship of Individual Student Normalized Learning Gains in Mechanics with Gender, High-School Physics, and Pretest Scores on Mathematics and Spatial Visualization . * +. In Physics Education Research Conference (pp. 1-14). Boise, Idaho.

Hothi, N., \& Bisht, S. (2013). Contemporary Physics Teaching using Mathematica Software. International Journal of Innovative Research \& Development, 2(2), 12-20.

Jayanthi, S. V., Balakrishnan, S., Lim Siok Ching, A., Aaqilah Abdul Latiff, N., \& Nasirudeen, A. M. A. (2014). Factors Contributing to Academic Performance of Students in a Tertiary Institution in Singapore. American Journal of Educational Research, 2(9), 752-758.

Jonassen, T. (2002). Mathematica as a teaching tool for a large audience of students. In International Arctic Seminar.

Katsikas, E., \& Panagiotidis, T. (2010). Student Status and Academic Performance: an approach of the quality determinants of university studies in Greece (No. 40).

Lázaro, M. (2015). Learning Mechanical Vibrations with Wolfram Mathematica. Modelling in Science Education and Learning, 8(2), 93

Lowry, C. M. (1989). Supporting and Facilitating Self-Directed Learning. ERIC Digest.

Malsawmtluanga, H. T., \& Fanai, L. (2018). A Study on Relationship between Home Environment and Academic Achievement among Secondary School Students of Champhai Town, Mizoram. International Journal of Academic Research and Development, 3(2), 214-217.

Mega, C., Ronconi, L., \& De Beni, R. (2014). What makes a good student? How emotions, self-regulated learning, and motivation contribute to academic Achievement. Journal of Educational Psychology, 106(1), 121-131.

Mokhasi, P., Adduci, J., \& Kapadia, D. (2012). Understanding Differential Equations Using Mathematica and Interactive Demonstrations. CODEE Journal, 9(1), 1-20.

Mudjiman. (2009). Belajar Mandiri. Surakarta: UNS Press.

Mushtaq, I., \& Khan, S. N. (2012). Factors Affecting Students' Academic Performance. Global Journal of Management and Business Research, 12(9).

Nalah, A. B. (2014). Self-Concept and Students' Academic Performances in College of Education, Akwanga, Nasarawa State, Nigeria. World J Young
Researchers, 3(2), 31-37.

Ningsih, Y. L., \& Jayanti, J. (2016). Hasil Belajar Mahasiswa melalui Penerapan Model Blended Learning pada Mata Kuliah Persamaan Diferensial. Jurnal Pendidikan Matematika JPM RAFA, 2(1), 1-11.

Nurseto, T. (2011). Membuat Media Pembelajaran yang Menarik. Jurnal Ekonomi Dan Pendidikan, 8(1), 19-35.

Putra, A. (2018). Tenaga Kerja Asing dan Politik Ketakutan. Retrieved August 24, 2019, from https:// news.detik.com/kolom/d-396529o/tenaga-kerja-asing-dan-politik-ketakutan

Rejeki, S., \& Setyaningsih, R. (2016). Kontribusi Kemampuan Kalkulus Differensial Dan Kalkulus Integral Terhadap Hasil Belajar Mata Kuliah Persamaan Differensial. Jurnal Ilmiah Pendidikan Matematika, 1(1), 63-70.

Remali, A. M., Ghazali, M. A., Kamaruddin, M. K., \& Tan, Y. K. (2013). Understanding academic performance based on demographic factors, motivation factors and learning styles. International Journal of Asian Social Science, 3(9), 1938-1951.

Sumarmo, U. (2004). Kemandirian Belajar: Apa, Mengapa, dan Bagaimana Dikembangkan Pada Peserta Didik Oleh: Utari Sumarmo, FPMIPA UPI. Makalah Pada Seminar Tingkat Nasional. FPMIPA UNY Yogyakarta, 1-9.

Tahar, I., \& Enceng. (2006). Hubungan Kemandirian Belajar Dan Hasil Belajar Pada Pendidikan Jarak Jauh. Jurnal Pendidikan Terbuka Dan Jarak Jauh, 7(2), 91-201.

Tarmidi, \& Rambe, A. R. R. (2010). Korelasi Antara Dukungan Sosial Orang Tua dan Self-Directed Learning pada Siswa SMA. Jurnal Psikologi (Yogyakarta), 37(2), 216-223.

Valle, A., Núñez, J. C., Cabanach, R. G., González-Pienda, J. A., Rodríguez, S., Rosário, P., Muñoz-Cadavid, M. A. (2008). Self-regulated profiles and academic achievement. Psicothema, 20(4), 724-731.

Yandari, I. A. V., Nindiasari, H., Khaerunnisa, E., Pamungkas, A. S., Karso, \& Nurjanah. (2018). Self-Regulated Learning in Designing Explorative Learning Tools Among Mathematics Pre-service Teachers through Explorative Module. In SHS Web of Conferences (Vol. 42, p. 00106).

Zumbrunn, S., Tadlock, J., \& Roberts, E. D. (2011). Encouraging Self-Regulated Learning in the Classroom: A Review of the Literature. Metropolitan Educational Research Consortium (MERC). Virginia: Virginia Commonwealth University. 